\title{
Media, Machines and Might: Reproducing Western Australia's Violent State of Aboriginal Protection
}

\author{
Thor Kerr and Shaphan Cox
}

\begin{abstract}
This paper addresses the prevalence of state violence directed at Aboriginal people. It examines how violence has been reproduced in recent years in the space of Western Australia through mutually-reinforcing relations of financial interest, and how the function of private capital accumulation - in state violence against sovereign Aboriginal people - has remained hidden in white sight. This paper argues that state violence is legitimized through a discourse of Aboriginal protection. After outlining how this discourse and violence have operated in Western Australia, the paper provides a substantive narrative challenging the routine reproduction of state violence against Aboriginal bodies through a close reading of public and media texts. These texts relate to state violence against a blockade preventing land-clearing machines from entering Aboriginal country in mid 2011; state violence against the Nyoongar Tent Embassy in early 2012; and, the government's announcement in May 2011 that it would amend the Aboriginal Heritage Act. Through this analysis, lines are drawn between media, machines and might for the purpose of enabling white sight to see private capital accumulation functioning within the reproduction of state violence against Aboriginal people.
\end{abstract}

Key words: media, representation, Aboriginal heritage, state violence, protection

Thor Kerr, a lecturer in Curtin University's Department of Communication and Cultural Studies, researches representation in public conversation. His latest book, To the beach: Community conservation and its role in 'sustainable development', examines public controversy and policy making around coastal property development in Western Australia.

Shaphan Cox, a human geographer in Curtin University's Department of Planning and Geography, researches contestations of space and place through representation. Recent publications include the co-authored book Setting up the Nyoongar Tent Embassy and the paper Negotiating the civic-heart of Fremantle: Past, present and critical perspectives of Kings Square.

How does state violence against Aboriginal bodies occur with such frequency and impunity?

This paper tries to answer the question by demonstrating how such violence has been reproduced in recent years in the space of Western Australia through mutually-reinforcing relations of financial interest. Through an analysis of texts produced by Western Australia's largest commercial media organization, Seven West Media, compared with alternative 
sources, this paper demonstrates how the function of private capital accumulation in state violence against sovereign Aboriginal people has remained largely hidden in public view, enabling the violence to proceed unchallenged through discourses of private capital accumulation and public Aboriginal protection. After briefly outlining how this discourse and violence have operated in Western Australia, the paper provides a substantive narrative challenging the routine account of state violence against Aboriginal bodies through an analysis of Seven West Media's news reports in comparison with other ways in which these news events have been represented. Seven West Media texts were analysed for this paper in relation to three events: 1) state violence against people forming an onshore blockade in the Browse Basin to prevent land-clearing machines from entering Aboriginal country in mid 2011; 2) state violence against the Nyoongar Tent Embassy in early 2012; and, 3) the Western Australian government's announcement in May 2011 that it would amend the Aboriginal Heritage Act. Through this analysis, lines are drawn between media, machines and might in demonstrating how private capital accumulation has enabled the reproduction of state violence against Aboriginal people.

\section{Background}

Criminal Law for the control of Aboriginal people in Western Australia was instituted by Governor Stirling in 1837, within the first decade of land grants in the Swan River area being issued to British men of capital by the Colonial Office in London (Hunter 2012: xxiv-xxv). The British invaders, as they were referred to by Stirling, ignored the land-occupation regulation and spatial organization of the invaded Aboriginal people, whose resistance to this social, economic and cultural disruption was met by the overwhelming violence of British capitalists, who mobilized servants and colonial troops to protect their enterprises on this land. The Colonial Office may have regarded its Perth settlement as private land speculation 
by capitalists, but it provided enough funds, labour and military might for the project to succeed. In his settlement proclamation, Stirling asserted that he could grant occupation rights to all 'unoccupied land' in the area. However, this wording was replaced by the term 'wasteland' in settlement regulations because the land was too obviously already occupied by Aboriginal people (Statham-Drew 2003). The early colonists rationalised their invasion through a discourse of economic efficiency which held that the land was not so much terra nullius as it was underutilised by Nyoongar people: The whites were better at exploiting the land and its people.

In the novel Benang, Kim Scott (1991) drew on his social experience and the Western Australian colonial archive to explore complex relations of state and colonist self-interest that were at work to naturalise a sickening violence that guaranteed Aboriginal poverty while breeding the blackness out of their bodies. In his later novel, That Dead Man Dance, Scott (2010) described the function of capital accumulation in early colonial violence but also possibilities for non-violence in Aboriginal-colonial interactions. Scott's work draws attention to the systemic function of capital accumulation in colonial violence; a function that was backgrounded as a discourse of Aboriginal protection was foregrounded in white descriptions of colonial-Aboriginal interactions. No longer seen as a solution to the problem of resistance to the invasion of Aboriginal country, state violence has come to be seen as a solution to the problem of Aboriginal people behaving inappropriately; of Aboriginal people refusing to recognise a role imposed on them.

Glen Coulthard (2014) has demonstrated how we tend to lose sight of the rationality of Aboriginal resistance through official renderings of settler colonialism as an historical event, rather than as a persisting social structure. Coulthard showed the means by which the Canadian state has maintained settler access to the territories of 'Indigenous peoples' for the purposes of state formation, settlement and capitalist development' (2014: 125). These means 
of dispossession have ranged from violence to legislation - through the Indian Act and other laws - to a more contemporary negotiated surrender of Aboriginal land under Canadian land claim policy. Patrick Wolfe $(2001,868)$ argues that 'settler colonialism seeks to replace the natives on their land', it's primary logic being their 'elimination'. Although characteristics have varied in different spaces of settler colonialization, actions to dispossess and eventually eliminate first nation people in North America and Australia have been driven by the 'bourgeois discourse of private property' (870) of settler colonists from Europe. This discourse has underpinned the notion of terra nullius and ubiquitous land enclosures in Australia through three strategic phases of settler colonisation: confrontation, carceration and assimilation (Wolfe 2001, 871). These overlapping and persisting phases can be identified in Western Australia. From early colonial massacres of Aboriginal people, such as at Pinjarra in 1834 (Statham-Drew 2003: 264-265), to systemic use of legislation legitimizing the removal - enslavement and early death - of Aboriginal people (Kinnane 2003: 18), to a more recent insistence by state government on the negotiated surrender of Aboriginal native title claims (McLean 2012: 346-347). The enduring colonial takeover of Aboriginal lands and bodies has been, and continues to be, legitimised by state legislation within a settler-colonial discourse of dispossession that renders Aboriginal people in need of protection from themselves.

The Aborigines Act 1905 (WA) was introduced 'to make provision for the better protection and care of the Aboriginal inhabitants of Western Australia' (1). Through the legislation, public servants were authorised to remove children and property from Aboriginal people in Western Australia. This Act was a forerunner in bureaucratic practices of Aboriginal protection that led to the systemic removal of Aboriginal children known commonly as the 'Stolen Generations' (Steering Committee for the Review of Government Service Provision 2014: 1.9). The protections afforded by this Act and subsequent variations would work to destroy Aboriginal families and Aboriginal connections with land, language 
and culture. In response Aboriginal activists have been seeking to reassert their sovereignty to get away from the state violence of protection. This is not an easy task with an everincreasing proportion of Aboriginal people being sent to jail and a sharply increasing proportion of Aboriginal Children being removed from their families in the decade to 2013 (Steering Committee for the Review of Government Service Provision 2014). Then amid a mineral recourse boom, Indigenous Affairs Minister Peter Collier announced it was 'timely that the Government considers reforms that might improve the protection and preservation of Aboriginal heritage' (Government of Western Australia 2011). In the following sections, news texts from Seven West Media - the media group with the most audience reach in Western Australia - will be analysed in relation to three state news events around Aboriginal heritage. The first event was the mobilization of police to break through a blockade preventing land-clearing machinery from entering Aboriginal country to establish drilling sites for the US $\$ 45$ billion James Price Point petroleum project in the Browse Basin. The second event was a series of violent police raids to evict the Nyoongar Tent Embassy at Matagarup in Perth, which was set up in solidarity with the $40^{\text {th }}$ anniversary of the Aboriginal Tent Embassy in Canberra and to voice concerns over an out-of-court settlement deal that would extinguishment native title to Nyoongar country. The third event was the Aboriginal Heritage Amendment Bill 2014. The analysis of texts from Seven West Media included a content analysis of The West Australian newspaper archive from 14 July 2004 to 22 January 2014. It also included qualitative analysis of articles - on the above events - in The West Australian on 12 April 2008, 28 April 2009, 6 July 2011, 25 July 2011, 8 August 2012, 15 February 2012, 17 February 2012, 24 March 2012 and 27 November 2014; a radio interview by The West Australian columnist Paul Murray on 6PR on 22 February 2012; and 7News broadcasts on 12 February 2012, 14 February 2012 and 21 February 2012. 
These popular news texts were analysed and compared with other ways in which the three events have been represented in other texts. Through this analysis, lines are drawn between media, machines and might to show how private capital accumulation functions within reproductions of state violence against performances of Aboriginal sovereignty. Confrontation, carceration and assimilation remain legitimate, this paper argues, because they and the interests they serve have been normalized in the white sight of the Western Australian public through discourses of private capital accumulation and public Aboriginal protection.

\section{Media and machines}

In its 2014 annual report, Seven West Media's Chairman, Kerry Stokes presented a message of confidence after Seven Network had 'marked its $8^{\text {th }}$ consecutive year of market leadership in Australian broadcast television with a primetime rating share of $39.7 \%$ and a record revenue share of 40.5 per cent' (Seven West Media 2014: 12). Seven West Media apparently had the capacity to not just help shape Australia's media landscape but also its audiences' understandings of important events, particularly in Western Australia where Seven News had almost twice the evening primetime audience of its nearest competitor. ${ }^{1}$ Meanwhile, Seven West's daily newspaper, The West Australian, was without a competitor in creating printed news for audiences in Perth and Western Australia:

The West Australian drives the news agenda and public opinion in Western Australia... Both the Monday-Friday edition and the Weekend West deliver among the highest market penetration of any Australian major metropolitan newspaper and The West Australian's online site thewest.com.au is the leading Western Australian news site. (Seven West Media 2014: 21)

Senior management at Seven West Media, evidently, were not ashamed of how their newspaper had driven the news agenda and public opinion in Western Australia, despite what this implies about influencing electoral outcomes, legislation and government policy (Lucy \& Mickler 2006). So if there is no debate about Seven West Media's claim using its substantial 
reach to shape public conversation, what would it be most interested in achieving? An examination of the structure of financial interest in Seven West Media may provide an answer.

Seven West Media is subject to a 35\% shareholding held by Kerry Stokes and to a $35 \%$ shareholding held by Seven Group Holdings, also chaired by Stokes. Before mentioning Seven West Media's leadership in 'confronting a difficult advertising market', Stokes was upbeat in a Chairman's Letter to Seven Group Holdings shareholders about its subsidiary WesTrac Australia, and its 'leadership in the mining, resources and infrastructure sectors in New South Wales and Western Australia' (Seven Group Holdings 2013: 2-3). WesTrac's success drove Seven Group Holdings' record AUD4.8 billion revenue in the 2013 financial year:

This is a record underlying result, reflecting the performance of the Company's industrial services businesses in Australia, with WesTrac Australia delivering significant growth in revenue and profitability, particularly in the first half of the financial year, benefiting from the growth in Australia's coal and iron ore mining sectors. (Seven Group Holdings 2013: 4)

Much of Seven Group Holding's revenue comes from the supply of industrial machinery to resource projects in Western Australia. How tempting must it be, then, for Seven Group Holdings to encourage Seven West Media to apply its capacity for driving 'news agenda and public opinion' in favour of removing impediments to resource projects in Western Australia, particularly when The West Australian's AUD303 million annual revenue pales in comparison to WesTrac Australia's AUD4.1 billion (Seven Group Holdings 2013: 8)? More links surface. In his first public address as Seven West Media's Chief Executive Officer, Don Voelte was critical of any federal government attempt to question the structure of media ownership. Voelte was promoted to head the media group in June 2012 after serving as a director of West Australian Newspapers Holdings from December 2008 (Seven Group Holdings 2013) while also acting as Woodside Petroleum's Chief Executive: 
Mr Voelte has significant experience in the global oil and gas industry and, prior to his retirement in June 2011, was the Managing Director \& Chief Executive Officer of Woodside Petroleum

Limited, a position he had held since joining the company in 2004. (Seven Group Holdings 2013: 24)

As Woodside's chief, Voelte was already known to the journalists and many readers of The West Australian. A search for 'Don Voelte' in the newspaper's archive on 23 January 2014, produced 453 texts. Compare this, for example, with a search for the 'United Nations Declaration on the Rights of Indigenous People' which yielded no results for the correct title of this landmark declaration and only two articles for its improper title. The two articles, published in the World section of the newspaper, related to first nation responses to the declaration in North America. No link was made to how important this declaration may be for readers of The West Australian in particular and the local resources industry in general. Instead of informing readers that Australia was one of only four United Nations members that had voted against the declaration in September 2007 and then - like three other recalcitrant Anglo-settler states - had subsequently endorsed it (Lightfoot, 2012), The West Australian gave its pages to positioning Voelte as a leading businessman in the oil and gas sector. In an article headlined, 'Voelte holds all the aces as gas train steams on' on page 72 on 12 April 2008, for example, the newspaper wrote that owing to Voelte's competence 'do not be surprised to see Woodside in the driver's seat when it comes to determining the running of a Browse LNG hub somewhere on the Kimberley coast'.

\section{Browse Basin and its onshore blockade}

The Browse Basin trough in the ocean off the Kimberley coast in the northwest of Western Australia reportedly holds ' $25 \%$ of Australia's recoverable reserves of natural gas' (O'Faircheallaigh 2012: 24). By 2005 it had apparently become feasible to develop Browse Basin by piping the gas onshore for processing into LNG condensate for export. In 2007, the 
state government established a taskforce to select a site for an onshore processing facility to be developed by Woodside Energy. O'Faircheallaigh (2012) argues that negotiations over site selection between the consortium, the state, the Kimberley Land Council and representatives of local native title claim groups proceeded in a relatively productive way for Aboriginal people until a change in state government in late 2008. The new Liberal government, headed by Colin Barnett, announced it would, compulsorily, acquire land from Aboriginal peoples at James Price Point for the project if they failed to give their consent within 3 months in a Heads of Agreement with the state and Woodside over the development of the onshore LNG Precinct. This was a controversial announcement because James Price Point was already subject to a combined native title claim of Goolarabooloo and Jabirr Jabirr people, but Premier Barnett sought popular support through the media by posturing that it was unacceptable for Aboriginal consent to veto projects (O'Faircheallaigh 2012). Under pressure to sign a Heads of Agreement in April 2009, members of the Goolarabooloo group walked out of a meeting in which some Aboriginal people endorsed the Kimberley Land Council's proposal to sign a Heads of Agreement that offered some protection, such as a management regime to minimise any impacts on Aboriginal cultural heritage and funding for an Aboriginal ranger program to undertake environmental and cultural heritage monitoring of the project (O'Faircheallaigh 2012). According to The West Australian on 28 April 2009, Woodside Chief Executive Don Voelte participated in the project's signing ceremony - amid protests - with Barnett and Kimberley Land Council Chief Executive Wayne Bergmann.

While the state government assessed the environmental impact of the project, a road blockade was established by Goolarabooloo people, other concerned locals and environmentalists to prevent land clearing and drilling equipment moving onto the site of the proposed onshore LNG facility. Community unity against the threat of damage to Aboriginal heritage and environment from the project was the subject of Eugenie Dumont's 2013 
documentary film, Heritage Fight. This documentary on the formation of an alliance between local Aboriginal people, local non-Aboriginal people and visiting environmentalists focussed on the alliance roadblock. In one scene police arrive to clear the dirt-road blockade and say that participants would violate the Road Traffic Act if they refused to move off the road. An elderly Aboriginal woman responds to the police by showing a print out of the United Nations Declaration on the Rights of Indigenous Peoples and by attempting to explain the legal basis of the alliance roadblock in reference to sections 16 and 18 of the state's Aboriginal Heritage Act 1972.

Without reference to these laws, The West Australian reported on 6 July 2011 that 25 people at the blockade had been arrested on charges of obstructing a police escort of Woodside machines. The article paraphrased a police official saying that 'police had a duty to enforce the law where protesters deliberately hindered or obstructed the lawful activity of others'. Aboriginal legal claims are not reported while claimants are rendered as protesters to be policed patiently. The article closes with Barnett being paraphrased from a 6PR radio interview saying that 'activists had every right to protest but they could not obstruct Woodside, which was going about its lawful business'. This dominant article on page 3 assimilates Aboriginal people into protesters clashing with police, getting themselves arrested for getting in the way of legitimate business. The article renders Aboriginal people law breakers amid the potentially problematic appearance of Wolfe's overlapping phases of colonisation. At most, an image and subsidiary article may solicit readers' empathy with the Aboriginal people being arrested at this blockade in an emotional defence of their country. However, even the caption for this image of policemen carrying away the passively-resisting elderly Aboriginal woman, Janet Cox, has been captioned 'Protest fury'.

Reporting on another large police action against the blockade a year later, The West Australian constructed the issue as a debate on whether too many police resources were being 
dedicated to breaking the blockade. Then, on 8 August 2012, an opinion article by the newspaper's former long-standing editor, Paul Murray, ${ }^{2}$ shifts debate away from unnecessary policing to criticism of an $\mathrm{ABC}$ television documentary for 'social activism masquerading as journalism'. Murray accused the ABC of failing to see that people forming the blockade were 'rent a crowd trying to stop the project', perhaps because '100 police officers' had been shown jogging alongside a Woodside machinery convoy (The West Australian's 15 May 2012). In fairness to Murray, Woodside was not asked to pay for this police crowd that vastly outnumbered blockade volunteers. Mobilization of this police crowd, to ensure Woodside's machinery convoy could enter Aboriginal land, cost taxpayers \$1 million (The West Australian, 16 May 2012, page 22). Murray's article, on the editorial page, suggests division between environmentalists against the project and Aboriginal people favouring it. This was consistent with Colin Barnett's representation, in state parliament on 9 May 2009, of a division between environmentalists and Aboriginals which he referred to in relation to 'Killing Land and Country' graffiti sprayed on a wall outside the Kimberley Land Council's office (Coyne 2009): 'I take this opportunity to call upon environmental groups, whatever their position on the Kimberley might be, to denounce this graffiti and these attacks on Aboriginal people who have worked long and hard to bring this project to fruition' (Western Australia, Legislative Assembly 2009, p.4153b) . However, images of police lifting Janet Cox from the blockade (The West Australian, 6 July 2011) suggested a more newsworthy divide between police and Aboriginal protester. Arguably, the a more hurtful division was created when the Barnett government insisted on overriding Aboriginal negotiations and choosing James Price Point for Woodside's LNG facility, an insistence which split the local Aboriginal community into those against the project and those for continuing negotiations within the government's constraining framework (O'Faircheallaigh 2012). 


\title{
Police raid the Nyoongar Tent Embassy
}

Barnett and Murray on talk-back radio created a divide between the broader Western Australian public and the Nyoongar Tent Embassy, which was established at Matagarup Aboriginal heritage site (ID. 3589) on Heirisson Island - in Perth on 11 February 2012 in response to a government-sponsored plan to extinguish native title to all but a fraction of Nyoongar country (Perth and the Southwest corner of Western Australia).

Rather than face a legal expert on indigenous rights, native title or Aboriginal heritage on Murray's show on 6PR on 22 February, Barnett confirmed the legal opinion offered in the form of a question from an apparently common man introduced to listeners by Murray as 'Karl in Spearwood':

\begin{abstract}
Karl in Spearwood: Yeah, Premier, I was just wanting your opinion in regards to this Tent Embassy that is going on at the moment on Heirisson Island. Um, in regards to them putting up a tent, I thought that was, ah, illegal; in regards to them lighting fires, I thought that was illegal, um, I thought you need a permit to protest and walk down St Georges Terrace, um, if Joe Blow was to do that they'd be fined for it. Why aren't these people fined?
\end{abstract}

Barnett: Ah, Karl, I think most people would agree with you and I would too....

The Premier took the media opportunity offered by Murray to defame the Nyoongar Tent Embassy as a public nuisance, instead of informing the public of the legal rights of the Aboriginal people, who had gathered at the state-recognised Aboriginal heritage site to discuss how to respond to his government's announcement of a plan to extinguish native title to all but a fraction of Nyoongar country. In return for Nyoongar people accepting this radical extinguishment of native title, the Western Australian government would pay $\$ 700$ million to Nyoongar corporations in annual instalments over 20 years (South West Aboriginal Land and Sea Council 2012).

Without the antagonizing presence of police and city rangers attempting to evict the embassy, this paper's authors found the Nyoongar Tent Embassy to be peaceful during their weekly field trips in February and March 2012. Its usual form was a circle of people gathered 
around a sacred fire. Participants practiced traditions, made music, danced, laughed and discussed the complexities of Aboriginal social order. It was one of the few public places in Perth where visitors could hear Aboriginal people talk about their lives in the city and their struggles for state and municipal recognition of their rights described in the United Nations Declaration of Indigenous Rights.

The peace of this place was broken intermittently in February and March 2012 (Kerr \& Cox 2013): First by City of Perth's CEO delivering an eviction notice to the embassy, then by increasingly confronting police raids and subsequent incarceration of embassy participants, invasive practices by media workers and abuse shouted by strangers driving over the causeway bridge and cruising up the river. Rather than representing this action as a breach of the peace, popular news represented the Tent Embassy as a threatening menace at Perth's city gates. Media coverage tended to construct a 'problem' of Aboriginal 'protesters' (Kerr \& Cox 2013: 6), a problem to be policed.

Seven West Media supported this construction of the tent embassy. There was a noticeable shift early in its news reporting on the tent embassy with the titles of 7News items shifting from “"Tent Embassy” in central Perth' on 12 February 2012 to 'Aboriginal protesters to stay put' on 14 February. The West Australian newspaper followed this shift, from 'Tent activists snub order' on 15 February 2012 to 'Protesters refuse to move' on 17 February 2012. Once Nyoongar Tent Embassy participants had been assimilated in popular media representation as the 'protesters' to be policed instead of Aboriginal people with a legal and legitimate reason for peaceful assembly, The West Australian's editors could focus on dividing them from Perth's community and state-funded Aboriginal organizations. The newspaper's editorial for 24-25 March 2012, headlined: 'Island protesters need to take a constructive role', blamed the Nyoongar Tent Embassy for social divisions constructed against it by Seven West Media and other popular news organizations. The cartoon associated 
with this editorial was headlined ' 6 weeks ago, some unwelcome guests arrived... in our ceiling'. The cartoon represented Perth's inhabitants as white people taking violent action to rid their house of non-human black pests. State violence against the tent embassy participants is legitimised in the associated editorial through description of an apparently threatening and unreasonable menace: 'there were complaints about the group, alleging disorderly conduct, threats to members of the public, damage to public property and fires being lit illegally'. The editorial elides Seven West Media's role in producing this threat and positioning embassy participants outside 'the public':

Police had to use force to move the group on and, despite a complaint that a pregnant woman holding a baby was bumped by a police horse, they handled the matter well. It is reasonable to ask why a pregnant woman with a 13-week-old baby was involved in such a situation in the first place.

Instead of criticising an extreme act of unwarranted police aggression towards a member of the public, the editorial lauded the 'commendable patience' of police. Similarly, 7News on 21 February 2012 suggested that police were needed to protect Aboriginal children from being hurt as they accompanied their boisterous protester parents causing traffic hazard as they marched through the streets of Perth. This was a sophisticated construction by 7 News using the coincidence of voiceover and visual editing in suggesting unreliable parenting causing danger for 'Young children holding banners wandering in the road'. In cross referencing this event, a reporter not directly associated with Seven West Media, suggested that hazard for these children did not come from their parents or the vehicles slowed by the march; rather it came from 'a plastic bottle of water... thrown from an apartment block, narrowly missing children carrying an Aboriginal flag, before exploding on the road' (AAP 2012). Reproducing a long-standing settler colonial discourse of protection, the 7News report covertly legitimized what was - at that time - an increasing rate of state removal of Aboriginal children from their families (a simultaneous act of confrontation, carceration and 
assimilation) while remaining silent on real dangers facing Aboriginal children from other members of the public apparently intent on their destruction.

The West Australian legitimised police raids by claiming that the Nyoongar Tent Embassy was excluding members of the public from a City of Perth Reserve. On the authors' field trips, there was no evidence of this exclusion. However, there was an obvious exclusion about 100 metres away, across the Swan River, where fences had been installed behind which earth-moving machines were clearing the way for the multi-billion dollar Waterbank property development, instigated by the municipality and Lend Lease corporation (Hassell 2015). In contrast to the Waterbank project which disrupted public pleasure, traffic and pedestrian flows, it should have been obvious to journalists - particularly when told - that the embassy 'isn't blocking progress in terms of development. We're hardly in view of public sight as you can see' (Kerr \& Cox 2013: iii). However, Seven West Media represented the embassy as a threat to public safety and pleasure, while not saying that international, federal and state law suggests that this Aboriginal gathering on federally-recognised Nyoongar country at a staterecognised Aboriginal heritage site was legal. Instead, the legal and colonial context of the tent embassy was left to Aboriginal media (The Koori Mail, 7 March 2012).

\section{Ensuring an inheritance of loss: amending the Aboriginal Heritage Act}

At James Price Point, Aboriginal heritage was evoked to prevent capitalist machines from entering Aboriginal lands. This is why control over the management of Aboriginal heritage remains a key priority of contemporary settler colonialism in Western Australia. As the blockade was coming together on the road to James Price Point, Indigenous Affairs Minister Peter Collier announced the appointment of a consultant 'to assist in the reform of Aboriginal cultural heritage processes in Western Australia' (Government of Western Australia 2011). This resulted in two rounds of public consultation. The first round focussed on the 
government consultant's advice and its intention to reform the Aboriginal Heritage Act 1972

(WA). The second round was announced with the state government's release of its draft Aboriginal Heritage Amendment Bill 2014, ensuring 'Western Australia’s Aboriginal heritage is properly protected and managed' (Government of Western Australia 2014):

\footnotetext{
"This is the first meaningful change to the way we manage the protection of our Aboriginal heritage in 33 years," Mr Collier said.

"The pace of economic development in recent years, particularly within the mining and construction sectors, has highlighted inadequacies in the current legislation. "Modest changes are required to ensure that our Aboriginal heritage - a State asset of significant importance - can continue to be protected." (Government of Western Australia 2014)
}

While several resource companies expressed support for the amendment bill, most Aboriginal people and organizations did not. One reading of the public submissions argued that 95 percent 'of submissions were against the proposals' (Georagatos 2014). Concerns around the amendments focussed on a lack of Aboriginal consultation in their drafting and on the amendment bill threatening the Aboriginal objects and sites that it claimed to protect. The bill was criticised, by the Law Society of Western Australia, for not ensuring transparent reasoning of the newly introduced Chief Executive Officer's (CEO) determinations and for not guaranteeing Aboriginal people a voice in the decision-making process. Aboriginal MLA Ben Wyatt (2014: 3) submitted that 'the Government's proposed Amendments actually contemplate a reduced involvement for Aboriginal people than the original Act drafted in 1972'. Aboriginal academic Blaze Kwaymullina and Aboriginal author Sally Morgan (2012: 1) wrote that the government's plan would 'weaken a piece of legislation which is already failing to achieve the purpose of protecting Aboriginal heritage'. The architects of the bill seemed to ignore their opinion as well as Professor Mick Dodson and Gary Toone (2012) of the Australian National University, who submitted that 'Aboriginal people are the rightful determiners of heritage significance and value'. Aboriginal community groups and land councils expressed their grave concerns about the bill. Elders and Traditional Owners of the 
Swan River People (2014: 1) native title claim group saw it as 'a return to the days of the Chief Protector of the Native Welfare'.

When the bill was introduced to parliament by Health Minister Hames on 27 November 2014, it echoed colonial law from over a hundred years prior:

\begin{abstract}
The CEO's functions include the following - (a) to evaluate on behalf of the community the importance and significance of places and objects alleged to be associated with Aboriginal persons; ... (c) to recommend to the Minister places and objects that, in the opinion of the CEO, are, or have been, of special significance to persons of Aboriginal descent and should be preserved, acquired and managed by the Minister (Aboriginal Heritage Amendment Bill 2014 (WA): 4)
\end{abstract}

The Chief Protector may undertake the general care, protection, and management of the property of any Aboriginal or half-caste, and may - (1.) Take possession of, retain, sell, or dispose of any such property (Aborigines Act 1905 (WA))

The government ignored repeatedly expressed concerns of Aboriginal people in drafting and reviewing its Aboriginal Heritage Amendment Bill. Despite the government's rhetoric about increasing Aboriginal involvement and safeguarding their heritage, the bill enables its appointed Chief Executive Officer (CEO) to determine, in his/her own opinion, what is and what is not Aboriginal heritage. The 'CEO decides what goes on or is removed from' the register of Aboriginal sites and objects (Aboriginal Heritage Amendment Bill 2014 (WA): 28). The bill allows appeals of CEO decisions preventing the disruption of Aboriginal heritage but not appeals of CEO declarations 'that there is no Aboriginal site on the land' (9). The bill opens the way for machines to invade Aboriginal lands; with confrontation, incarceration and assimilation of Aboriginal people likely to follow.

Instead of reporting community outrage over an impending injustice, The West Australian (27 November 2014), informed readers the bill was needed to stop Aboriginal exploitation in the form of 'white consultants... charging exorbitant fees for survey reports'. This is how Seven West Media's flagship newspaper introduced the amendments to readers, on the day the bill was introduced to parliament. The newspaper's page 1 headline read: 
'HERITAGE RORT: Approval process flaws and hold-ups cost $\$ 100 \mathrm{~m}$ a year'. It fell to The West Australian to construct public acceptance of legislation detested by Aboriginal people.

\section{Conclusion}

This paper demonstrates how media, machines and might function in contemporary phases of settler colonisation in Western Australia: The media subsidiary of a conglomerate - mostly funded by resource-extraction machinery business - has an interest in driving 'news agenda and public opinion' (Seven West Media 2014: 21) towards support for what has been constructed as 'Aboriginal protection', the might of state violence that enables extraction machinery to invade Aboriginal lands. Unless the mutually-reinforcing interests reproduced through this structure are highlighted and challenged it seems certain that colonisation will continue. This paper suggests these interests can operate without much constraint until they become too well known. They seem to have been constrained by the news spectacle of police lifting Janet Cox from the roadblock preventing convoys of machines deployed by Woodside. They were also constrained when Goolarabooloo elder Richard Hunter and the Wilderness Society stopped Woodside's project in its tracks by demonstrating that bureaucrats determining the project were not disinterested in it. Since then a plethora of potential conflicts of interest between Woodside and the Environmental Protection Authority as well as the Department of Aboriginal Affairs have been identified (Western Australia, Legislative Assembly 2014). This paper argues that the lines between media, machines and might in Western Australia are not so much conflicts of interests but the normal relations of settler colonization.

\section{Notes}

1. By 2012, Seven News had a 22.9\% share of the evening television audience, followed by TEN News with a $12.1 \%$ share, ABC1 with $12.0 \%$ and Nine News with $11.1 \%$ (Kerr \& Cox 2013).

2. Paul Murray has worked for The West Australian for over 30 years. After studying geology and working in Kalgoorlie gold mines, he followed his father into a job at the newspaper. He was the newspaper's editor from 
1990 to 2000, when he moved to talk-back radio at 6PR before returning to the newspaper in 2006 as a columnist (Platinum Speakers n.d.).

\section{References}

AAP, (2012), 'Aboriginal protest march in Perth', viewed 3 July 2015,

<http://www.perthnow.com.au/news/breaking-news/aboriginal-protest-march-inperth/story-e6frg $12 \mathrm{u}$ 1226277104026>

Aboriginal Heritage Amendment Bill 2014 (WA).

Aboriginal Heritage Act 1972 (WA).

Aborigines Act 1905 (WA).

Coulthard, Glen Sean (2014), Red Skin, White Masks: Rejecting the Colonial Politics of Recognition,

Minneapolis: University of Minnesota Press.

Coyne, Darren, (2009), 'Unions, Land Council in Deal', viewed 3 July 2015, <http://www.cpa.org.au/guardian/2009/1412/10-unions-land-council.html>

Dodson, Mick \& Toone, Gary, (2012), Submission on the 'Review' of the Western Australian Aboriginal Heritage Act 1972, viewed 6 February 2014, <http://www.daa.wa.gov.au/PageFiles/1842/aha-DodsonToone.pdf>.

Heritage Fight, documentary film, directed by Dumont, Eugenie, Mitchell, ACT: Ronin Films, 2013.

Georagatos, Gerry, (2014), 'The Watering Down of the Heritage Act, a Racist Connivance', viewed 3 February 2014, < http://thestringer.com.au/the-watering-down-of-the-heritage-act-a-racist-connivance8481\#.VNRtLm3N3Qo>.

Government of Western Australia (2011), 'Minister announces appointment of Aboriginal Cultural Heritage consultant', viewed 7 July 2014,

$<$ http://www.mediastatements.wa.gov.au/pages/StatementDetails.aspx ?listName=StatementsBarnett\&S tatId $=4092>$.

Government of Western Australia (2014), 'Changes to protect State's Aboriginal

Heritage', viewed 26 August 2014,

<http://www.mediastatements.wa.gov.au/pages/StatementDetails.aspx ?listName=StatementsBarnett\&S tatId $=8395>$.

Hassell (2015), 'Waterbank', viewed 27 January 2014, <http://www.hassellstudio.com/en/cmsprojects/detail/waterbank>.

Hunter, Ann, (2012), A Different Kind of Subject: Colonial Law in Aboriginal-European Relations in Ninteenth Century Western Australia 1829-61, North Melbourne: Australian Scholarly Publishing.

Kinnane, Stephen, (2003), Shadow Lines, Fremantle: Fremantle Arts Centre Press.

Kerr, Thor \& Cox, Shaphan, (2013), Setting up the Nyoongar Tent Embassy: A report on Perth Media, edited by Robert Briggs, Niall Lucy and Steve Mickler. Perth: Ctrl-Z Press.

Kwaymullina, Blaze \& Morgan, Sally, (2012), Submission on the proposed changes to the Aboriginal Heritage Act 1972 (WA), viewed 6 February 2014,

$<$ http://www.daa.wa.gov.au/PageFiles/1842/Aboriginal\%20Heritage\%20Act\%20Submission1\%20(2).p $\mathrm{df}>$.

Lightfoot, Sheryl (2012), 'Selective endorsement without intent to implement: indigenous rights and the Anglosphere', The International Journal of Human Rights, 16:1, pp. 100-122.

Lucy, Niall \& Mickler, Steve, (2006), The War on Democracy, Crawley: UWA Press.

McLean, Jessica (2012), 'From Dispossession to Compensation: a political ecology of the Ord Final Agreement as a partial success story for Indigenous traditional owners', Australian Geographer, 43:4, pp. 339-355.

O'Faircheallaigh, Ciaran (2012), 'Extractive industries and Indigenous peoples: A changing dynamic?', Journal of Rural Studies, 30, pp. 20-30.

Platinum Speakers (n.d), Paul Murray’s Biography, viewed 6 February 2014, <http://www.platinumspeakers.com.au/Speakers/Paul-Murray.aspx>.

Scott, Kim, (1991), Benang, Fremantle: Fremantle Press.

Scott, Kim, (2010), That Dead Man Dance, Sydney: Pan Macmillan.

Seven Group Holdings, (2013), Annual Report 2013. Sydney: Seven Group Holdings.

Seven West Media, (2014), 2014 Annual Report: Leadership in Content. The Best Media Brands. Delivering the Biggest Audiences., Perth: Seven West Media.

South West Aboriginal Land and Sea Council, (2012). The Facts, viewed 31 October 2014, <http://www.noongar.org.au/images/pdf/forms/The\%20Facts\%20on\%20propsed\%20native\%20title $\% 2$ 0settlement\%20of\%20the\%20SW.pdf>.

Steering Committee for the Review of Government Service Provision, (2014), Overcoming

Indigenous Disadvantage: Key Indicators 2014, Canberra: Productivity Commission. 
Statham-Drew, Pamela (2003), James Stirling: Admiral and Founding Governor of Western Australia. Crawley, WA: University of Western Australia Press.

Swan River People, (2014), Re: Draft Bill Aboriginal Heritage Act, viewed 6 February 2014, <http://www.daa.wa.gov.au/Documents/HeritageCulture/Aboriginal\%20Heritage\%20Legislative\%20C hanges/Submissions/Swan\%20River\%20People_AHAB2014_20140804.pdf>.

Western Australia, Legislative Assembly 2009, Parliamentary Debates, pp. 4153b-4154a), viewed 6 February 2014,

<http://www.parliament.wa.gov.au/Hansard/hansard.nsf/0/afc099453b2628aec82575ca002d4d0c/\$FIL E/A38+S1+20090519+p4153b-4154a.pdf>.

Western Australia, Legislative Assembly 2014, Parliamentary Debates, pp.7409b-7428a, viewed 1 December 2014,

<http://www.parliament.wa.gov.au/Hansard/hansard.nsf/0/a20bb7ead238a12148257d780014b3fe/\$FIL E/C39+S1+20141016+p7409b-7428a.pdf>.

Wolfe, Patrick, (2001). 'Land, Labor, and Difference: Elementary Structures of Race', The American Historical Review, 106:3, pp. 866-905.

Wyatt, Ben, (2014). Aboriginal Heritage Act Amendment Bill, Submission to Department of Aboriginal Affairs, viewed 6 February 2014,

<http://www.daa.wa.gov.au/Documents/HeritageCulture/Aboriginal\%20Heritage\%20Legislative\%20C hanges/Submissions/Ben\%20Wyatt\%20MLA_AHAB2014_20140806.pdf>. 